\title{
Counter-effect of Refugee Movement in Culturally and Linguistically Diverse Classrooms
}

\author{
Ekrem Solak $^{1, *} \&$ Betül Bal Gezegin ${ }^{1}$ \\ ${ }^{1}$ Faculty of Education, Department of English Language Teaching, Amasya University, Amasya, Turkey \\ *Correspondence: Faculty of Education, Department of English Language Teaching, Amasya University, Amasya, \\ Turkey. E-mail: ekremsolak@gmail.com \\ This Project was funded by Amasya University with Project Number SEB-BAP 17-0129
}

Received: January 18, 2019

Accepted: March 13, 2019 Online Published: March 18, 2019

doi:10.5430/wje.v9n2p22

URL: https://doi.org/10.5430/wje.v9n2p22

\begin{abstract}
The presence of refugee students in culturally and linguistically diverse classrooms relatively influences the development of local students as well. Students with different languages and cultural background in a learning environment create a different atmosphere and may influence the attitude of local students to other languages and cultures. Therefore, this study investigated how and to what extent native students were influenced from refugee students in terms of linguistic and cultural perspective. The mixed method was used in this study. Quantitative data were collected from local students in culturally and linguistically diverse classrooms through a questionnaire and qualitative data were collected from teachers teaching in these classrooms by means of interviews. The results of the study revealed that there were remarkable positive effects of the integration process on both sides though various problems emerged in diverse classrooms. The findings of this research may also give implications about the influence of refugee movement for other cultures.
\end{abstract}

Keywords: refugee education, refugee students, language, cultural integration

\section{Introduction}

People have been leaving their homes for centuries due to wars, interior conflicts, terror, human rights violations and violence in search of better life conditions. According to the United Nation (UN) statistics, at the end of 2016, more than 65,6 million people were identified as refugees and this number is higher than the population of the United Kingdom. One person in three seconds or 20 persons in a minute become a refugee all over the world (http://www.unhcr.org/uk/). Syrians are in the first place in the refugee movement with a population of 12 million, and Colombians are the second with 7,7 million. Next, Afgans are 4,7 million and Iraqies are 4,2 million. Children under 18 constitute half of the all refugee population in the world (http://www.un.org/).

The current surge of refugees has always been considered as a challenge for the receiving countries. Turkey is facing an inrush of refugees as a transit country and it is in the first place in admitting 3,2 million refugees successively within three years. Due to its geographical position, Turkey accepted many refugees from Syria, Iraq and Afghanistan for humanitarian purposes as a result of conflicts in the region. Given the fact that Turkey is home to more than 1.2 million child refugees, and is the top child refugee hosting country in the world, education of these children has currently become a chief concern. Today, there are about 78.000 refugee students enrolled in public state schools in Turkey and the number is estimated to increase rapidly when the birth rates and the gradually increasing number of refugees are taken into consideration. Refugee students under the age of 18 are registered for training mostly in refugee camps but there are still 13\% deployed out of these camps in Turkey. During this training and integration process, linguistic and cultural integration of refugee students plays a crucial role, because education is not possible without linguistic and cultural knowledge. In 2016, there are 108.000 international students in Turkish Universities and 14,747 of them are Syrian refugee students. Increasing better access to schools and strengthening the conditions for the refugee students have recently become prior goals of the government, national education administrators, educators and NGOs.

In culturally and linguistically diverse classrooms, the presence of minority language background students also 
influences the development of Turkish-born students in some aspects. Students with different languages and cultural background in a learning environment create an unusual atmosphere and may influence the attitude of local students to other languages and cultures. Therefore, this study focuses on counter-effect of refugee movement and aims to investigate the linguistic and cultural influence of minority language backgrounds on Turkish-born students in Turkish education context. The results of this research may give implications about the influence of refugee movement for other cultures as well.

\section{Review of Literature}

Starting in April 2011, Turkey has become host to over 2.7 million Syrian refugees due to the war started in Syria. After opening its doors to refugees, Turkey has become the most popular destination with a percentage of $44 \%$ Syrian refugees compared to other neighbor countries like Lebanon (29\%), Jordan (16\%), Iraq (5\%), and Eygpt (\%3) (Birleşmiş Milletler Mülteciler Yüksek Komiserliği (BMMYK), November, 2014). The refugees who live in urban cities $(66 \%)$ as well as in 22 refugee camps (34\%) in Turkey were regarded as guests in the beginning. However, the current situation in Syria and the fact that refugees not returning to their home countries and willing to be long-term residents have led to recent discussions on refugees. They cannot be described as "guests" anymore but potential legal citizens. This brings along a compelling case, a challenge and an increasing concern for Turkey. Turkey has to cope with social, societal, economical, and educational problems that come with the mass flows of refugees.

Being one of these issues, the current status of education for refugees has a short but dynamic history. When the refugees first started to come to Turkey, since it was anticipated that they would return to their home country when the war is over, the education was planned as a short term, auxiliary contribution for refugees. Therefore, in 2012 the ministry of education has announced that the courses would be in their native language, Arabic, and the students would not receive any degrees or diplomas at the end of their training. However, as aforementioned, the current situation of refugees has changed, and this yielded revisiting and renewal of educational policies. Refugees in need of education are now placed in schools as citizens and are expected to be a part of the classrooms in Turkish based on the Turkish curriculum.

Their being a part of the education system at schools has brought along various challenges on minority language backgrounds, and native students as well as teachers. School administrators, teachers, parents and students have been experiencing unexpected cases due to incoming minority language backgrounds. This current situation of education of/with minority language backgrounds has drawn attention in both sociological and psychological studies as well in the field of education. Previous studies focusing on the education of refugee children show that these students have to struggle with many problems due to cultural, linguistic, and social challenges they encounter during their education (Kirova, 2001; Suarez-Orozco, 2001). Although studies reporting the current phenomena in Turkey are limited for the time being, the number of studies particularly focusing on pedagogical effects of integrating refugee students in the existing education system has increased recently. There are limited numbers of studies reporting the perceptions and opinions of various participants such as teachers, and university students from different regions of Turkey.

Yaylaci-Göktuna and Karakuş (2015) carried out a study to find out how senior students attending the faculty of education perceive multiculturalism and refugees. This qualitative case study which was conducted through interviews with the participation of 12 prospective teachers attending their final year at tertiary level suggested that in general, participants had positive thoughts about the refugees, but they also had some concerns about the future of refugees. Uzun and Bütün (2016) interviewed 6 preschool teachers who had refugee students in their classes in a particular city in Turkey in order to identify the main problems they face in their classrooms. The common theme found in the interviews was that refugee children had serious problems because they did not speak Turkish, the language of local students.

Ergin (2016) conducted a study at a university in the Marmara Region of Turkey and surveyed what Turkish students' opinions were on the Syrian guests' access to the higher education in Turkey. The findings suggested that local students at universities who had refugee classmates had positive thoughts and attitudes towards the refugees' participation in higher education; however, they also had serious concerns about their access to and right for higher education in Turkey. Er and Bayındır (2015) carried out a quantitative study to specify the pedagogical approaches of 182 elementary teachers for primary level of refugee students and reported that $74 \%$ of participant teachers reported to have no knowledge regarding the education of refugee children although they had many problems.

In another study, Aydın and Kaya (2017) investigated the views of school principals and teachers serving in İstanbul, Turkey about the needs of Syrian refugee students. This study was qualitative and eight participants who had Syrian 
refugee students in their classes and wider school environment participated. The findings of the study revealed that Turkish public schools provided many Syrian children in Istanbul with an access to education and secure learning environment though poor school conditions, the shortage of sufficiently trained teachers for refugees, inadequate resources and inappropriate curriculum planning hinder the high-quality education.

Erdoğan et al. (2017) carried out a study on the problems and expectations of Syrian refugee academics and university students resided in Turkey. They interviewed the target group, administered questionnaires and arranged workshops. The results of the study had various implications, yet in terms of language proficiency, while $37 \%$ of the participants had advanced Turkish language proficiency, $41 \%$ were at the intermediate level. As for English proficiency, 31\% of the participants were at the advanced level. Memişoğlu and Ilgıt (2017) studied the recent Syrian Refugee case in Turkey in certain aspects. They made an in-depth analysis of Turkey's asylum policy in terms of security, humanitarian and socio-economic dimensions. In their study, they found that Turkey's Syrian refugee policy does not contain a clear analytical framework especially on the roles of various local actors.

\section{Method}

This study investigated how and to what extent native students (Turkish) were influenced from refugee students in terms of linguistic and cultural perspective. In the literature, there were numerous studies on the effect of local language and culture on refugee students, but this study analyzed the phenomenon from a different view point. The mixed method was used in this study. According to Creswell and Clark (2006), mixed research is the collection and analysis of both quantitative and qualitative data in single and multiples studies in a research program. Therefore, in this study, both qualitative and quantitative data were collected to make an in-depth analysis of the subject matter.

The following research questions were answered in this study.

(1) Was there a statistically significant difference between Turkish-born students' views on minority language background students' language and culture with that of gender?

(2) Was there a statistically significant difference between Turkish-born students' views on minority language background students' language and culture with that of academic achievement?

(3) How do the teachers perceive minority language background students' cultural and linguistic effect on the Turkish-born students?

\subsection{Sample Group}

The quantitative part of the study was administered at a high school at a province in Turkey. In this school, Both Turkish and refugee students were trained in the same learning environment in culturally and linguistically diverse classrooms. The age range of the participants was between 15 and 17.73 male and 123 female students, totally 196, responded the questionnaire. They had English and French language courses, and these offered an opportunity for Turkish students to get to know a foreign language and culture. At this school, there were 30 refugee students at different grades. The native language of the refugee students was Arabic, and their English level was graded as intermediate by language teachers.

The data for the qualitative inquiry were collected at two different high schools in the same province. Semi-structured individual interviews with two teachers (T1, T2) in the former school and focus group interviews with four teachers (T3, T4, T5, T6) in latter school were carried out. The reason why these schools were chosen as the research setting was that based on the statistics obtained from the directorate of National Education, these schools had the highest number of refugee students. Also, most of the refugee students were placed at high schools to pursue their education. Therefore, in these target schools, it was more convenient to find teachers who had more contact with refugee students and more experience of interacting with them in their classrooms. In this research, purposeful sampling method was used.

The main criteria while choosing the participants was whether the teachers had minority language background students in their classrooms and had an opportunity to observe them in their educational settings. The number of years of teaching experience of these teachers ranged from 10 to 25 . All of the teachers who participated in this study had refugee students in at least one of their classes and they had known these students for at least one year. Further information about the teachers interviewed can be found in the table below. 
Table 1. Descriptions of Teachers as Participants

\begin{tabular}{llcc}
\hline Participants & Gender & Year of Teaching Experience & Teaching Field \\
\hline T1 & Female & 12 & Turkish Language \\
T2 & Male & 15 & English Language \\
T3 & Female & 16 & Vocational Courses \\
T4 & Female & 20 & Geography \\
T5 & Male & 25 & Religion \\
T6 & Male & 22 & Mathematics \\
\hline
\end{tabular}

\subsection{Data Collection Instrument}

Two main data collection tools were benefited in this study; a questionnaire for the students and interviews for the teachers. For the purpose of preparing questionnaire for the students, at first, researchers conducted some preliminary interviews with some language teachers and Turkish-born students at the high schools about their views on the language and culture of refugee students. Based on these interviews and the review of literature, 46 items were structured and five academics, who were specialized in language and culture studies, revised the items in terms of its content and language. The questionnaire was designed in Turkish language to provide a better understanding of the items. It was a five-point likert-scale ranged from "I totally disagree (1)" to "I totally agree (5)". Upon the statistical analysis of the data collected, the items having the value of lower than 0,70 were eliminated and finally the questionnaire was composed of 18 items with Cronbach Alpha value of 0,73. This 18-item questionnaire, Cultural and Linguistic Interaction Questionnaire, was administered to 200 Turkish students attending at a high school at various grades. Upon SPSS analysis of the data collected, 196 participants were found to respond the questionnaire in a valid and reliable manner. In other words, 4 respondents made invalid markings on the questionnaire and thus their responses were not taken into consideration.

For the purpose of obtaining the opinions of teachers, the semi-structured interview form for data collection was developed by researchers. The form consisted of mainly ten open-ended and interpretative questions. The essential question adressed was how presence of minority language background students in the same educational setting changed the Turkish-born students. Each interview lasted for approximately 45 minutes. In the focus group interview, the group observer was one of the researchers who made audio recordings of the sessions and took notes for further analysis. The analysis was carried out in three phases: (1) data preparation: the transcription of interviews and the write up of notes; (2) data identification: the coding and organization of the data of the text into analytically meaningful segments; (3) and data manipulation: the finding, sorting, retrieving, and rearranging of segments of data in order to find common themes and interpret the findings. The findings were given along with direct quotes in a way to reflect the participants' opinions.

\section{Results}

The data collected in this study was analyzed in SPSS program and presented in tables in accordance with the research questions. Table 2 below displayed if there was a significant difference between views on culture and gender.

Table 2. Difference Between Views on Culture and Gender

\begin{tabular}{lllllll}
\hline gender & $\mathbf{N}$ & $\mathbf{X}$ & ss & Sd & t & p \\
\hline female & 123 & 29.76 & 6.28 & 194 & -3.23 & .001 \\
male & 73 & 26.66 & 6.82 & & & \\
\hline
\end{tabular}

$$
\mathrm{p}<.05
$$

According to t-test results, there was a statistically significant difference between the views of native students on culture and gender $(\mathrm{t} 194=-3.23, \mathrm{p}<.01)$. The mean of female students $(\mathrm{X}=29.76)$ was higher than male students $(\mathrm{X}$ $=26.66)$. This data revealed that a significant difference was observed in favor of female students. In other words, Turkish female students had more positive views about the refugee students' culture. Table 3 indicated if there was a significant difference between views on culture and academic achievement. 
Table 3. One-way ANOVA Test Results on the Views of Culture and Academic Achievement

\begin{tabular}{llllllll}
\hline $\begin{array}{l}\text { The Level of } \\
\begin{array}{l}\text { Academic } \\
\text { Achievement }\end{array}\end{array}$ & $\begin{array}{l}\text { Dependent } \\
\text { Variable }\end{array}$ & N & X & SS & F & p & $\begin{array}{l}\text { Significant } \\
\text { Difference } \\
\text { (Tukey) }\end{array}$ \\
\hline Very good & Views on culture & 29 & 28.03 & 7.24 & & & - \\
good & views on culture & 52 & 27.36 & 6.77 & 1.924 & .13 & \\
average & views on culture & 83 & 28.94 & 6.19 & & & \\
low & views on culture & 22 & 31.27 & 7.22 & & \\
\hline
\end{tabular}

$\mathrm{p}<.05$

According to One-way ANOVA test, there was no statistically significant difference between views on culture and academic achievement $(\mathrm{F}=1.924 ; \mathrm{p}>.05)$. In other words, the views of high or low performing Turkish students about refugee students' culture didn't show any differences. Table 4 showed if there was a significant difference between views on language and gender.

Table 4. The Difference between Views on Language and Gender

\begin{tabular}{lllllll}
\hline Gender & $\mathbf{N}$ & $\mathbf{X}$ & ss & Sd & t & p \\
\hline female & 123 & 18.04 & 5.10 & \multirow{2}{*}{194} & -2.13 & .035 \\
male & 73 & 16.48 & 4.72 & & & \\
\hline
\end{tabular}

$\mathrm{p}<.05$

According to t-test results, there was a statistically significant difference between the views of native students on language and gender $(\mathrm{t} 194=-2.13, \mathrm{p}<.05)$. The mean of female students $(\mathrm{X}=18.04)$ was higher than male students $(\mathrm{X}=16.48)$. This data showed that a significant difference was observed in favor of female students. In other words, Turkish female students had more positive views about the refugee students' language. Table 5 displayed if there was a significant difference between views on language and academic achievement.

Table 5. One-way ANOVA Test Results on the Views of Language and Academic Achievement

\begin{tabular}{llllllll}
\hline $\begin{array}{l}\text { The Level of } \\
\text { Academic } \\
\text { Achievement }\end{array}$ & Dependent Variable & N & X & ss & F & p & $\begin{array}{l}\text { Significant } \\
\text { Difference } \\
\text { (Tukey) }\end{array}$ \\
\hline very good & views on language & 29 & 16.21 & 4.98 & & & \\
good & views on language & 52 & 16.79 & 5.61 & 2.69 & .048 & $4-1$ \\
average & views on language & 83 & 17.59 & 4.25 & & & \\
low & views on language & 22 & 19.86 & 5.68 & & &
\end{tabular}
$\mathrm{p}<.0 \overline{5}$

According to One-way ANOVA test result, there was a statistically significant difference between views on language and academic achievement $(\mathrm{F}=2.69 ; \mathrm{p}<.05)$. Tukey test as a post hoc test was administered to investigate the source of the difference at the end of the analysis. According to this result, a significant difference was observed between the first group (high performers) and fourth group (low performers) and this significant difference was in favor of low performers. In other words, low-performing students had more positive views on the language of the refugee students than high-performing students.

Based on the interpretive data analysis, this section of the paper reports the findings of interviews with teachers who have refugee students in their classrooms. It includes the explorations about the participants', namely teachers' perspectives on refugee students from both a broader and more specific point of view. The teachers were asked questions based on their general thoughts on refugee students and on refugee students' cultural and linguistic influence on local students. The answers were explained under three main themes based on the interview data as, 1. Perceptions of teachers on refugee students, 2. Perceptions of Teachers Towards Refugee Students' Cultural Influence on Local Students, and 3. Perceptions of Teachers Towards Refugee Students' Linguistic Influence on Local Students. 


\subsection{Perceptions of Teachers Towards Refugee Students}

The interviews began with general questions on what teachers thought of refugee students having education in Turkish state schools. The answers were very similar in the sense that all the teachers had critical approach to the system in whole. They reported that refugee students being integrated in classroom needs to be preplanned and should be carried out with care. They stated that in the current situation there were many problems stemming from unplanned organization of the system. These problems reported by teachers during the interviews can be listed as:

1. The most important problem is with language. Refugee students cannot talk Turkish. Therefore, they have almost no interaction with their classmates or teachers. They cannot follow the courses because they are in Turkish. In addition, they cannot take exams because all the exams are in Turkish. Teachers are obliged to give grades to the refugee students, and they are confused about what to do.

2. There is no certain time that these students register and enroll in courses. All of a sudden in the middle of a semester refugee students are sent to classrooms by the provincial directorate of national education. This means that they had missed all previous courses; therefore, they find it difficult to follow the curriculum.

3. Refugee students have financial problems. They cannot buy school uniforms, or any material needed for school.

4. There is a serious attendance problem with refugee students. After a certain time, since they cannot understand the courses, they start to miss the courses.

5. They encounter social problems. If there is one refugee student in the classroom, s/he chooses to be lonely. If there is more than one student, they form groups and do not interact with local students. They speak in their own language and prefer not to be a part of the classroom.

6. Teachers have no background information about the refugee students coming to their classrooms. They do not know about their level of proficiency, which course they had taken previously, whether or not the course they are taking is beyond or above their level, what their needs are, whether or not they have special needs.

7. Tension is observed with refugee students. They get involved in fights with Turkish-born students in and out of the school. These fights change how Turkish-born students view refugees. Their positive thoughts easily change to negative when a fight of a refugee student is reflected on media.

In general, all the teachers who participated in the study expressed positive views on refugee students since they tried to empathize with them. However, they also stated that having a refugee student in the classroom means having many responsibilities and troubles due to the problems mentioned above. They believed that if conditions were improved and precautions were taken and if all the preparations were made in advance, having a refugee student in classroom would not be a burden but richness instead.

\subsection{Perceptions of Teachers Towards Refugee Students' Cultural Influence on Local Students}

In order to understand whether or not refugee students have any cultural effect on local students, during the interviews the teachers were asked two main questions. The first question was:

"Do you think that refugee students have any cultural influence on local students?"

All the teachers who had either positive or negative thoughts on refugee students reported that refugee students had positive cultural influence on local students. They believed that refugees brought "richness, color and variety" in their classrooms. Local students who had never contacted with a foreigner before had a chance to see in real that there are different languages, cultures and nationalities in the world.

The next question for the same topic was;

"Have you experienced any case in which local students' views have changed with regard to refugees' culture?"

One of the teachers (T1) explained with an anecdote how one of her refugee students had a positive effect on her students with regard to culture.

"One summer day, we were having our Turkish lesson and suddenly we heard wedding ceremony music outside. We heard drums and zurna being played outside and car horns. The refugee student in our classroom was not able to understand what was going on. She started to look around to ask someone what was going on. She was puzzled. All my local students were so surprised to see that she did not know that was wedding ceremony music. This was a very usual sound for them, and they had never thought that this might confuse or even startle someone. I began explaining that this was a wedding ceremony and there was nothing to be afraid of. Then my local students started telling that they were curious about the weddings in my refugee students' home country. We kindly asked her if she would like 
to tell us about their weddings. She was so happy about it and she accepted to prepare a presentation about their weddings. I helped her to find the materials for her presentation such as pictures, music etc. In our next class, she did her presentation and I had never seen my local students so motivated, curious and attentive in my classrooms before. This was a great memory not only for me but also for my refugee and local students. This presentation changed many things in my classroom. It not only helped the refugee student to be a part of the classroom and had a chance to talk but also helped my local students to learn about a culture that they had no idea of."

As seen in this quotation above refugee students bringing elements from their own cultures to the classroom contributed to teaching and learning in many ways. Another teacher (T2) also shared a memory from her own experience with a refugee student who had family problems and lost her father.

"She (referring to the refugee student) was always very silent and sad. I and her classmates thought that it was because she cannot speak Turkish. However, we learnt that indeed she was able to communicate in Turkish. But the problem was that her father was very ill. One day she did not come to class and we learnt that she lost her father. We planned a visit to her family. I and a group of teachers and classmates visited her family. Our visit to their home changed many things in our way to look at refugees in general. We were so surprised to see her living conditions. She had many siblings who needed care. They had no furniture at home. She was so ashamed that she could not serve anything to drink or eat at home. She served glasses of water because that was all they had. The most significant thing was that it was the first time we experienced how people with different cultures gave their condolences. All my students who were with me were so surprised to see the rituals that were taking place during our visit. When my students came back to school from this visit, they shared their experience with other classmates. After this visit, the way they behave towards refugee students, the way they speak to them changed a lot. Those who never spoke to the refugee student in my classroom began asking questions like "How do you do this in your culture?" They became more welcoming and thoughtful not only towards that refugee girl in our classroom but also to other refugees in our school".

\subsection{Perceptions of Teachers Towards Refugee Students'Linguistic Influence on Local Students}

The language phenomenon in the case of refugee students' education at public schools in Turkey have many facets: refugee students resisting to learn Turkish, refugee students trying to learn Turkish, refugee students speaking only English, refugee students who believe they can speak English but never talk, local students trying to interact in Turkish (to teach Turkish), local students trying to interact in English, local students who oppose refugees speaking in their own language, and local students who have become curios in learning the mother tongue of refugees.

Language was found to be the most significant barrier that limited refugee students' being a part of the group that they were in. However, teachers in this study indicated that this language barrier yielded outcomes that were not anticipated. The interaction between the local and refugee students who could not find a common language was so valuable. Drawings, body language, signs, and dictionaries were always used in these interactions. All the teachers reported that most of the local students put effort to find a way to interact with the refugee students. This led to a more dynamic atmosphere in the classroom.

The views of teachers on language issue in this study vary based on their teaching field. It was observed that teachers whose profession was related to teaching language as in the case of T1 (Turkish teacher) and T2 (English teacher) had a lot to tell about the linguistic influence of refugees on local students. These teachers were more observant of the phenomenon and regarded language as the key issue with the whole refugee education system in Turkey. They also explained that language issue had a dual effect on both local students and refugee students. Both of these groups suffered from the language barrier but most strikingly they also benefited from this situation. In language classrooms, these teachers observed that both of the student groups realized the significance of language for human interaction. Their position as the students sometimes turned to teachers while trying to teach their own language to the other group. The teachers reported that they were happy to hear students uttering sentences like "how do you say this in your language?", "I wish I could speak his/her language", "I did not know language was so important", and "I wish I could understand her/him".

Interviewing these teachers who had refugee students showed that there is lack of attention being paid to language issue. They think that if there is more dialogue between the national policy makers, schools, teachers and refugee students, this language barrier can indeed turn to an advantage and contribute to the general situation as an advantage for both parties. 


\section{Discussion and Conclusion}

This study investigated how and to what extent Turkish-born students were influenced from refugee students in terms of linguistic and cultural perspective. Studies reporting the current situation of the refugee students in Turkey were in surge. These studies included analysis of educational policies about refugees (Alpaydin, 2017), problems regarding educating refugees (Akkaya, 2013; Arabaci et al., 2013), teachers' practices in classrooms with refugee students (Erden, 2013; Emin, 2016); refugee students' experiences (Döner, Özkara, \& Kahveci, 2013) and local students' perspectives on refugee students (Ergin, 2016). However, studies on how refugee students affected local students were limited. Therefore, this paper exclusively focused on the cultural and linguistic effects of the integration of refugees in public schools in Turkey. Based on the quantitative data collected, female students had more positive attitudes than male students towards the refugee students' language and culture. In addition, there was no significant difference between academic achievement and local students' views on the refugee students' culture. In the relevant literature, studies did not focus on this aspect of refugee influence on local students.

The qualitative findings of this study revealed that although the teachers involved in the study had many problems in their classes, they were still in favor of international diversity in their classrooms. Although previous studies which had the same focus revealed contradicting findings (Windle \& Miller, 2013; Rutter, 2006; Hattam \& Every, 2010), teachers in the study had higher motivation to teach refugee students and were willing to interact with them and help them to enhance their learning. They expressed that their classrooms with refugee students changed the traditional atmosphere of their teaching context and the cultural diversity brought color and richness in their classrooms. Although their responsibilities increased, and they had to overcome a number of problems, they enjoyed seeing refugee students in their classrooms. Similar findings were also observed by Aydin and Kaya (2017) who concluded that teachers had a largely positive attitude towards Syrian students and sincerely tried to help them. The teachers also reported that although local students had trouble in getting used to be with refugee students who cannot speak with them due to their lack of language, the students still had positive attitudes towards their refugee classmates. The teachers added that when the local students were told to feel empathy with the refugee students and tried to understand them and put themselves in their places, local student became more sensitive, thoughtful and helpful towards their refugee classmates. A similar finding was also observed by Ergin (2016) who also reported that the participant students had generally positive attitudes towards their classmates when they spent time together.

Secondly, the study showed that in addition to teachers' positive attitudes towards refugee students, they also had positive views on how refugee students affected local students in terms of culture and language. They reflected how local students enjoyed the transition from single-cultural classrooms to multi-cultural classroom. The teachers explained that talking about different cultures from people who belonged to that culture or hearing a different language spoken around them rather than Turkish or English made students become more curious and motivated in their classrooms. Language was reported to be the prior problem in the refugee students' education. Since the refugee students could not speak Turkish, it became a trouble for them to follow the courses, make their assignments, take their exams or even contact with their classmates. The teachers stated they observed local students trying to teach Turkish to their refugee classmates or vice versa. This created a dynamic atmosphere in which there was always a mutual teaching/learning, sharing and helping took place. The teachers also reported that when this relationship was not formed in their classrooms, more problems arouse due to the lack of effort to communicate one way or another. If their refugee students and local students reject to communicate and become polarized, then they form their own groups as locals and refugees which created social loneliness, tender and disconnectedness in the classroom. This was also observed by Çetin (2016) who reported that lack of connection in classroom caused the refugees to form clusters among themselves and develop tendencies towards social and spatial structures that were broken from society.

In conclusion, there were remarkable positive effects of the integration process on both sides though various problems emerged in inclusive education. Participation in joint activities in diverse learning contexts, such as group homes, part-time work, NGOs, sports and other communities can promote the interaction between local and refugee students. Reforming refugee education as a part of diverse learning contexts in and outside of school may help both sides to recognize each other and create an awareness to promote collaboration between parties (Pastoor, 2017). The concept of linguistic relativity which was identified as the influence of a language and culture on its speakers' world view or cognition should be introduced to understand the diversities in the world. By this means, handicaps can be converted into opportunities that people can understand and learn from each other. 


\section{References}

Akkaya, A. (2013). Suriyeli mültecilerin Türkçe algıları [Syrian refugees' perceptions of Turkish language]. Ekev Akademi Dergisi, 17(56), 179-190.

Alpaydın, Y. (2017). An analysis of educational policies for school-aged Syrian refugees in Turkey. Journal of Education and Training Studies, 5(9), 36-44. https://doi.org/10.11114/jets.v5i9.2476

Arabacı, İ. B., Başar, M., Akan, D., \& Göksoy, S. (2014). An analysis about educational problems in camps in which Syrian refugees stay: Condition analysis. International Journal of Social Sciences \& Education, 4(3), 668-681.

Aydin H., \& Kaya Y. (2017). The educational needs of and barriers faced by Syrian refugee students in Turkey: a qualitative case study. Intercultural Education, 28(5), 456-473, https://doi.org/10.1080/14675986.2017.1336373

Çetin, İ. (2016). Türkiye'de Suriyeli sığınmacıların sosyal ve kültürel Entegrasyonu. Sosyoloji Dergisi, 34, 197-222.

Creswell, J., \& Clark, P. (2006). Designing and conducting mixed methods research. SAGE Pub.: USA

Döner, P., Özkara, A., \& Kahveci, R. (2013). Syrian refugees in Turkey: numbers and emotions. Lancet, 382(9894), 764. https://doi.org/10.1016/S0140-6736(13)61823-1

Emin, M. N. (2016). Türkiye'deki Suriyeli çocukların eğitimi: Temel eğitim politikaları. Seta.

Er, A. R., \& Bayındır, N. (2015). Pedagogical approaches of elementary teachers for primary refugee children. Uluslararast Sosyal ve Eğitim Bilimleri Dergisi, 2(4), 175-185. https://doi.org/10.20860/ijoses.08223

Erden, O. (2013). Experiences of a Syrian family in social and educational context: Case study. Paper presented at the International Conference on Gender and Migration: Critical Issues and Policy Implications, Istanbul, Turkey.

Erdoğan, M., Erdoğan, A., Yavcan, B., Mohamad, T., Kavukçuer, Y., \& Sanc1, G. (2017). "Elite Dialogue: Türkiye'deki Suriyeli Mülteci Akademisyen ve Üniversite Öğrencilerinin Durumu, Sorunları ve Beklentileri Araştırması, Ankara.

Ergin, H. (2016). Turkish university students' perceptions towards their Syrian classmates. Education and Science, 41(184), 399-415. https://doi.org/10.15390/EB.2016.6214

Hattam, R., \& Every, D. (2010). Teaching in fractured classrooms: Refugee education, public culture, community and ethics. Race, Ethnicity and Education, 13(4), 409-424. https://doi.org/10.1080/13613324.2010.488918

Kirova, A. (2001). Loneliness in immigrant children: Implications for classroom practice. Childhood Education, 77, 260-267. https://doi.org/10.1080/00094056.2001.10521648

Lutine de Wal Pastoor (2017). Reconceptualising refugee education: exploring the diverse learning contexts of unaccompanied young refugees upon resettlement. Intercultural Education, 28(2), 143-164. https://doi.org/10.1080/14675986.2017.1295572

Memisoglu M., \& Ilgit, A. (2017). Syrian refugees in Turkey: multifaceted challenges, diverse players and ambiguous policies. Mediterranean Politics, 22(3), 317-338. https://doi.org/10.1080/13629395.2016.1189479

Refugees with numbers by United Nations. Retrieved 01.04.2018 from http://www.unhcr.org/uk/news/stories/2017/6/5941561f4/forced-displacement-worldwide-its-highest-decades.ht $\mathrm{ml}$

Refugees. Retrived 01.04.2018 from http://www.un.org/en/sections/issues-depth/refugees/

Rutter, J. (2006). Refugee children in the UK. Maidenhead: Open University Press.

Suárez-Orozco, C., \& M. Suárez-Orozco. (2001). The Children of Immigration in School. Cambridge, MA: Harvard University Press.

Uzun, M., \& Bütün, E. (2016). Okul öncesi eğitim kurumlarındaki Suriyeli sığınmacı çocukların karşılaştıkları sorunlar hakkında öğretmen görüşleri. Uluslararası Erken Çocukluk Araştırmaları Dergisi, 1(1), 72-83.

Windle, J., \& Miller, J. (2013). Marginal integration: The reception of refugee-background students in Australian schools. In L. Bartlett \& A. Ghaffar-Kucher (Eds.), Refugees, immigrants, and education in the global south: lives in motion. New York: Routledge.

Yaylacı-Göktuna, F., \& Karakuş, M. (2015). Perceptions and newspaper coverage of Syrian refugees in Turkey. Migration Letters, 12(3), 238-250. https://doi.org/10.33182/ml.v12i3.277 